\title{
KEBERAGAMAN MOTIF DALAM CERITA RAKYAT ULAR RENGGIONG DAN PUTRI GUNUNG LABU DARI BELITUNG TIMUR: ANALISIS MOTIF MODEL STITH THOMPSON
}

\author{
Variety of Motifs in Folktale of Ular Renggiong and Putri Gunung Labu from East Belitong: \\ Analysis of Thompson's Motif Index of Folk Literature \\ Dwi Oktarina \\ Kantor Bahasa Kepulauan Bangka Belitung \\ Kompleks Perkantoran dan Permukiman Terpadu Provinsi Kepulauan Bangka Belitung \\ Jalan Pulau Bangka, Air Itam, Pangkalpinang, Indonesia \\ Pos-el: dwi.oktarina@kemdikbud.go.id
}

Naskah masuk: 11 Mei 2020, disetujui: 6 Juni 2020, revisi akhir 21 Juni 2020

\begin{abstract}
Abstrak
Kabupaten Belitung Timur yang masuk ke wilayah Provinsi Kepulauan Bangka Belitung me miliki kekayaan budaya sastra lisan, khususnya cerita rakyat yang belum banyak dikaji. Selain cerita rakyat, wilayah ini juga kaya akan pantun, syair, mantra, juga peribahasa. Penelitian ini bertujuan untuk mendeskripsikan keberagaman motif cerita rakyat dalam dua legenda, yakni "Ular Renggiong" dan "Putri Gunung Labu" berdasarkan klasifikasi Motif Indeks Stith Thompson. Kajian ini termasuk ke dalam jenis penelitian kualitatif. Metode yang digunakan adalah metode deskriptif analisis. Kedua cerita menggambarkan kondisi sosial budaya masyarakat Melayu Belitung yang masih sangat kental menjaga tradisi dan adat dalam kehidupan. Setelah dianalisis, didapatkan hasil cerita "Ular Renggiong" memiliki sembilan motif, sementara "Putri Gunung Labu" memiliki 15 motif. Hal ini menandakan keberagaman motif cerita rakyat yang ada di wilayah Belitung Timur.
\end{abstract}

Kata kunci: cerita rakyat, Belitung Timur, motif indeks, Thompson

\begin{abstract}
East Belitung Regency in Bangka Belitung Province has it cultural richness includes diversity in anything that has to do with how people live. This region has it oral literary culture, especially folklore like folktale, pantun, syair, mantras, as well as proverbs. This study is focused on the motifs in the folktale. This research aimed to describe the motifs of the folktale "Ular Renggiong" and "Putri Gunung Labu" based on Thompson motif index classification. This research is a qualitative research using descriptive analysis method. Both folktale showed the socio-cultural conditions of the Belitung's people who are still very strong in maintaining traditions and customs in life. The story of "Ular Renggiong" has 9 motives while "Putri Gunung Labu" has 15 motifs based on the Thompson Index Motif theory. This indicates the diversity of folktale motifs in the East Belitung region.
\end{abstract}

Keywords: folklore, East Belitung, index motif, Thompson

\section{Pendahuluan}

Keberadaan cerita rakyat saat ini banyak terlupakan. Sebetulnya, cerita rakyat adalah satu bagian dari sastra lisan yang sangat penting fungsinya dalam kehidupan. Sastra lisan memiliki fungsi yang menjadikannya sangat menarik serta pen-ting untuk diselidiki oleh ahli ilmu masyarakat dan psikologi dalam rangka melaksanakan pembangunan bangsa
(Danandjaja, 1984:19). Sastra lisan merupakan bentuk kearifan lokal yang berkembang secara dinamis dan menjadi salah satu pranata sosial masyarakat yang tidak terpisahkan dari tradisi tutur suatu masyarakat.

Sastra lisan adalah teks sastra yang dituturkan secara lisan. Selain itu, sastra lisan merupakan bagian dari folklore (tradisi lisan) yang memiliki ciri-ciri tertentu 
Dwi Oktarina: Keberagaman Motif dalam Cerita Rakyat Ular Renggiong dan...

yang berkaitan dengan ciri kesusasteraannya. Teks atau wacana ini bernilai sastra, memenuhi kualifikasi sebagai "karya sastra" yang memiliki kaidah estetik dan puitik tersendiri dengan sifat-sifat dan sarana kesusasteraan (Taum, 2011:24).

Sastra lisan memiliki fungsi penting dalam kehidupan karena dapat mencerminkan nilai-nilai kehidupan masyarakat. Sebagai tradisi tutur, sastra lisan melibatkan masyarakat secara langsung dan berakar dalam kehidupan sehari-hari. Sastra lisan dapat menjadi alat perekam situasi kebudayaan yang berkembang di tengah-tengah masyarakat. Ciri kebudayaan satu masyarakat juga dapat dipelajari lewat keberadaan sastra lisan yang dimiliki.

Setiap daerah pada dasarnya menyimpan kekayaan budaya sastra lisan yang bisa jadi belum terdokumentasi dengan baik. Salah satu alasan penghambat, yakni kurangnya referensi atau bahkan penutur yang memang sudah tidak ada lagi. Hingga saat ini, kajian atau penelitian mengenai sastra lisan, khususnya yang ada di wilayah Kepulauan Bangka Belitung, belum banyak yang didokumentasikan.

Secara umum, Provinsi Kepulauan Bangka Belitung yang terdiri atas tujuh kabupaten dan kota memiliki kekayaan sastra lisan yang beragam. Dalam pergaulan sehari-hari masyarakat lokal, orang-orang dapat dengan mudah membedakan mana sastra lisan berupa pantun, mantera, atau bahkan cerita rakyat. Meski demikian, hal itu tidak berlaku bagi seseorang dengan latar belakang bukan berasal dari wilayah budaya Melayu. Oleh sebab itu, diperlukan kajian secara lengkap dan terperinci sehingga menambah referensi terkait sastra lisan khususnya bagi pembaca dengan latar belakang nonbudaya Melayu.

Kabupaten Belitung Timur adalah salah satu bagian dari Provinsi Kepulauan Bangka Belitung yang memiliki khazanah perbendaharaan sastra lisan yang cukup ba-nyak. Pada umumnya, sastra lisan yang ada di wilayah ini disampaikan dalam bentuk tuturan berbahasa Melayu Belitung. Arif dkk dalam Aliana (1992) mengemukakan bahwa sastra lisan bahasa Melayu Belitung ada yang berupa puisi seperti betiong, begubang, campak, pantun, syair, mantra, peribahasa, dan prosa berupa cerita rakyat.

Ibrahim (2015) menyebutkan dalam laporannya bahwa cerita rakyat Belitong terdiri atas legenda, dongeng, mitos, hikayat, toponimi, sage, fabel, dan parabel. Menurut hasil wawancara, setiap kampung memiliki cerita rakyat masing-masing karena hal tersebut diceritakan secara turun-temurun dari orang-orang yang lebih tua ke generasi di bawahnya.

Selama ini, cerita rakyat Belitung Timur yang sudah dipublikasikan masih terbatas hanya beberapa terbitan saja. Cerita rakyat yang terbit pada buku Sastra Lisan Bahasa Melayu Belitung (1992) misalnya adalah cerita "Pulau Pandan", "Asal Mula Kejadian Pulau Belitong", "Riwayat Raja Beikor", "Telaga Muyang Manis", "Padang Buang Anak", "Antu Berasuk", "Keramat Menangan", "Datuk Letang", "Keramat Gadong", "Kucing kan Harimau", "Rengit Gede", dan masih banyak cerita lain.

Selain itu, Dinas Kebudayaan dan Pariwisata Kabupaten Belitung Timur (2018) juga menerbitkan Cerita Rakyat dari Belitung Timur yang menampilkan tujuh cerita rakyat yaitu, "Ular Renggiong", "Kunyit Emas dan Istana Bawah Air Sungai Lenggang", "Legenda Keramat Sisilan", "Yak Gana", "Asal Muasal Gendang Tiong", "Putri Gunung Labu", "Antu Kedondong", serta "Mak Celinggis dan Pelanduk".

Salah satu cara mengungkap keberagaman motif cerita adalah dengan menggunakan model analisis Stith Thompson. Motif didefiniskan sebagai anasir terkecil dalam sebuah cerita yang memiliki daya tahan dalam tradisi (Taum, 2011: 87). Secara lebih lengkap, Danandjaja (1984: 53) menyebut bahwa motif adalah unsur suatu cerita (narratives elements). Motif teks suatu cerita rakyat adalah unsur dari cerita itu yang menonjol dan tidak biasa sifatnya.

Taum (2011:88) mengelompokkan beberapa motif yang biasa dijumpai dalam cerita rakyat, yakni motif berupa 1) benda, 2) hewan, 3) konsep larangan/tabu, 4) perbuatan, 5) penipuan, dan 6) tipe orang tertentu.

Sementara itu, Thompson (1946 488500) mengklasifikasikan cerita berdasarkan motifnya, yakni 1) mythological motifs, 2) 
Dwi Oktarina: Keberagaman Motif dalam Cerita Rakyat Ular Renggiong dan...

animal, 3) taboo, 4) magic, 5) the dead, 6) marvels, 7) ogres, 8) tests, 9) the wise and the fools, 10) deception, 11) reversal of the fortune, 12) ordaining the future, 13) chance and fate, 14) society, 15) rewards and punishments, 16) captives and fugitives, 17) unnatural cruelty, 18) sex, 19) religion, 20) traits of character, 21) humor, dan 22) miscellaneous groups of motifs. Konsep yang dikemukakan Thompson lebih detail dalam menjelaskan motif cerita sehingga dapat diterapkan untuk mendeskripsikan cerita-cerita rakyat.

Berdasarkan inventarisasi cerita rakyat yang sudah ada, kajian ini difokuskan pada dua cerita rakyat, yakni cerita rakyat "Ular Renggiong" dan "Putri Gunung Labu" yang berasal dari wilayah Belitung Timur. Masalah yang dititikberatkan dalam kajian ini adalah apa saja motif dalam cerita rakyat "Ular Renggiong" dan "Putri Gunung Labu" berdasarkan klasifikasi Motif Indeks Thompson.

Penelitian ini bertujuan untuk mendeskripsikan motif cerita rakyat "Ular Renggiong" dan "Putri Gunung Labu" berdasarkan klasifikasi indeks motif Thompson. Selain itu, penelitian ini bertujuan untuk mendokumentasikan warisan budaya berupa sastra lisan dalam bentuk cerita rakyat khas masyarakat Belitung Timur.

Beberapa penelitian sudah banyak mengkaji hal-hal yang berkaitan dengan cerita rakyat asal Bangka Belitung. Sarman mengkaji "Mitos dalam Cerita Bukit Tambun Tulang" (2014). Dalam pandangan Levi-Strauss, mitos adalah dongeng yang dihasilkan oleh daya nalar manusia yang berkaitan dengan aspek-aspek kebudayaan tertentu. Kisah dalam mitos menggambarkan budaya komunitas pemiliknya, sarat dengan aspek khayalan, sindiran, juga bersifat edukatif. Bukit Tambun Tulang berada di wilayah Kabupaten Bangka Barat dan mitos mengenai keberadaan buluh perindu di bukit ini masih hidup dan berkembang di masyarakat Bangka hingga sekarang.

Sementara itu, Imelda (2015) mengkaji "Perbandingan Cerita Rakyat Si Kelingking (Jambi dan Bangka Belitung). Hasil penelitian menunjukkan terdapat persamaan unsur instrinsik yang dibahas dengan pendekatan struktural. Sementara itu, untuk perbedaan antara kedua cerita terdapat pada tokoh dan penokohan serta latar dalam cerita.

Sarman mengkaji "Representasi Kearifan Lokal Masyarakat Belitung dalam Cerita Keramat Pinang Gading" (2016). Hasil penelitian menunjukkan tidak ada peran dominan antara laki-laki dan perempuan dalam struktur relasi gender. Sementara itu, nilai kearifan lokal yang muncul adalah sikap jujur, bertanggung jawab, musyawarah, gotong royong, dan kerja sama.

Sarman kembali mengulas dongeng di Bangka Belitung melalui kajian "Analisis Struktur Aktan dan Fungsional Dongeng Batu Karang Seribu" (2017). Dalam kajian kali ini, ia memilih dongeng "Batu Karang Seribu" di Bangka Barat untuk dikaji menggunakan teori struktural A.J. Greimas. Semua tokoh dalam cerita ini berperan sepenuhnya dalam analisis struktural. Dengan demikian, cerita "Batu Karang Seribu" memenuhi struktur aktan dan model fungsional A.J. Greimas.

Pada 2019, Sarman mengkaji "Cerita Batu Bagga dan Batu Balai: Sebuah Kajian Struktural Sastra Bandingan". Berdasarkan perbandingan yang dilakukan, tampak persamaan hadir pada tema, alur, tokoh dan penokohan dan latar. Sementara itu, perbedaan antara kedua cerita tampak pada tokoh dan penokohan, alur, latar, dan amanat.

Sementara itu, kajian cerita rakyat yang menggunakan teori motif indeks Thompson di antaranya dilakukan oleh Riana (2017) dengan artikel berjudul "Pemaknaan Motif Tabu dalam Cerita Rakyat di Wilayah Bekas Kerajaan Mulawarman, Kerajaan Hindu Tertua di Indonesia". Terlihat bahwa konsep tabu masih melekat dalam kehidupan bermasyarakat di wilayah Kutai.

Dalam kajiannya, "Herawati (2019) menelaah "Cerita Rakyat 'Aji Batara Agung Dewa Sakti' dan 'Putri Karang Melenu' dari Kutai Kartanegara (Kajian Motif Indeks Thompson)". Hasil kajian menyebut bahwa dua cerita rakyat tersebut memiliki delapan motif berbeda yang memiliki beberapa persamaan juga perbedaan.

Dari semua kajian yang sudah dilakukan, belum ada penelitian yang mengangkat analisis cerita rakyat di Bangka Belitung dengan mengunakan 
Dwi Oktarina: Keberagaman Motif dalam Cerita Rakyat Ular Renggiong dan...

teori Motif Indeks Thompson. Oleh sebab itu, penulis merasa perlu mengkaji cerita rakyat "Ular Renggiong" dan "Putri Gunung Labu" dengan menggunakan metode indeks Thompson untuk mengungkap motif dalam cerita rakyat tersebut.

\section{METODE PENELITIAN}

Kajian ini termasuk ke dalam jenis penelitian kualitatif, yakni studi yang penekanannya berhubungan dengan aktivitas, situasi, atau bahan yang memerlukan deskripsi utuh tentang sesuatu. Metode yang digunakan adalah deskriptif analisis. Yang digunakan sebagai sumber data adalah cerita rakyat "Ular Renggiong" dan "Putri Gunung Labu".

Metode deskriptif digunakan dalam menjabarkan cerita rakyat dengan deskripsi kata-kata yang diikuti dengan analisis cerita. Tidak hanya deskripsi murni, tetapi juga dilakukan pengambilan simpulan atas fakta-fakta secara logis.

Adapun teknik penelitian dilakukan dalam dua cara, yaitu 1) pengumpulan data dan 2) analisis data. Teknik pengumpulan data dilakukan dengan menggunakan teknik studi pustaka, yakni membaca kedua cerita rakyat secara terperinci lalu mengelompokkannya menjadi sekuen-sekuen tertentu. Sementara itu, analisis data dilakukan dengan cara menganalisis sekuen sehingga akan ditemukan motif cerita yang ada di dalamnya. Hal terakhir yang dilakukan adalah mengambil simpulan atas analisis yang dilakukan.

\section{HASIL DAN PEMBAHASAN}

Cerita rakyat "Ular Renggiong" dan "Putri Gunung Labu" masuk ke dalam antologi Cerita Rakyat dari Belitung Timur yang diterbitkan oleh Dinas Kebudayaan dan Pariwisata Kabupaten Belitung Timur Tahun 2018. Dua cerita ini memiliki alur yang menarik untuk dikaji.

Sebelum mengetahui motif yang terkandung di dalam kedua cerita, perlu adanya pembagian sekuen dalam cerita yang akan memudahkan dalam proses menganalisis. Chatman (1975: 316-317) mengungkap bahwa dalam menganalisis struktur naratif harus dibagi menjadi unitunit fungsi segmen yang disebut sebagai sekuen, yakni rangkaian kejadian yang berupa urutan logis yang terbentuk karena adanya hubungan yang erat. Sekuen itu dapat berupa satu kalimat atau rangkaian kalimat.

\subsection{Cerita "Ular Renggiong" Sekuen I}

Di sebuah kampung di pedalaman Belitung, hiduplah seorang janda yang memiliki tiga anak perempuan. Si Sulung, Tengah, dan Bungsu namanya. Mereka terbiasa hidup sederhana dan memanfaatkan bahan-bahan yang tersedia di alam untuk dijadikan sebagai bahan makanan.

Suatu hari, saat hendak memasak nasi, mereka kehabisan sumber api. Jika mereka tidak menemukan api, mereka tidak bisa memasak. Akhirnya mereka akan kelaparan. Untuk mencegah hal tersebut, Ibu menyuruh si Sulung untuk meminta api kepada Ular Renggiong yang berada di tepi hutan dekat rumah mereka. Ular Renggiong dikenal garang dan kasar. Si Sulung akhirnya bertemu dengan Ular Renggiong dan meminta api kepadanya. Akan tetapi, ada syarat yang harus dipenuhi yakni $\mathrm{Si}$ Sulung harus mau menikah dengan Ular Renggiong. Permintaan itu ditolak mentahmentah oleh Si Sulung. Ia tidak mau menjadi istri binatang melata. Ia pun gagal membawa pulang api yang dibutuhkan.

Di rumah, Ibu kemudian mengutus si Tengah untuk mendatangi kembali Ular Renggiong. Senasib dengan kakaknya, si Tengah juga harus mau menikah dengan Ular Renggiong jika ingin mendapatkan api yang mereka butuhkan. Permintaan itu lantas ditolak kembali oleh Si Tengah. (Isral, 2018: 1-4).

Dalam Sekuen I, dapat diketahui beberapa motif yang tampak dominan. Yang pertama adalah motif P252.2 Three Sisters (tiga bersaudara perempuan). Dalam cerita "Ular Renggiong", seorang janda hidup bersama tiga anak perempuannya. Meskipun lahir dari rahim yang sama, ketiga anak perempuannya memiliki tabiat yang berbeda. Hal itu akan tampak pada beberapa ujian yang hadir pada kehidupan mereka yang miskin.

Tiga bersaudara itu adalah Si Sulung, Tengah, dan Bungsu. Ketiganya diberi tugas oleh ibunya untuk mendapatkan api sebagai bahan bakar memasak. Sayangnya, api tersebut hanya bisa didapatkan dengan cara meminta kepada 
Dwi Oktarina: Keberagaman Motif dalam Cerita Rakyat Ular Renggiong dan...

Ular Renggiong. Tugas yang diberikan oleh ibunya tersebut tidak diselesaikan dengan penuh tanggung jawab oleh si Sulung dan Tengah. Hal ini sesuai dengan motif P236. Undutiful Children.

Sulung dan Tengah memiliki kesamaan sikap, yakni kurang bertanggung jawab atas tugas yang telah diberikan kepada mereka. Kedua kakak beradik itu cenderung membebankan tugas tersebut kepada si Bungsu. Perbedaan sifat yang dimiliki oleh ketiga anak perempuan tersebut membuat tugas meminta api akhirnya diselesaikan oleh si Bungsu. Dengan penuh keberanian, si Bungsu dapat meminta api kepada Ular Renggiong.

Ular Renggiong adalah sosok hewan yang diketahui memiliki kesaktian tinggi dan ditakuti oleh orang-orang. Motif ketiga yang ditemukan pada Sekuen I ini adalah B211.61 Speaking Snake (Ular yang Berbicara).

Dalam mitologi dunia, ular menjadi bagian cukup penting dan melegenda. Ular dan berbagai simbol yang menyertainya seperti naga dikenal di hampir setiap budaya. Kita bahkan mengenal varian ular naga dalam tradisi lisan kita. Nunes (2015: 422) menyebut bahwa Propp mengilustrasikan simbol ular bersifat kosmogonal yang artinya merepresentasikan penciptaan alam semesta. Oleh sebab itu, ular juga berhubungan dengan air, api, gunung, dan gua (tanah).

Ular juga menjadi simbol favorit dari beberapa cerita dongeng. Pemujaan terhadap ular sebagai binatang yang suci juga ada di India dan Yunani kuno. Hal yang sama juga terjadi di wilayah British Raya dan semenanjung Skandinavia (Wake, 2020:373-374).

Selain karena kekuatannya, ular juga menjadi lambang kebijaksanaan. Tradisi Ibrani menyebut bahwa ular adalah binatang yang paling halus dan selembut merpati (Wake, 2020: 378). Dalam narasi cerita "Ular Renggiong", tokoh ular dihubungkan dengan konsep garang dan kasar sehingga ia sangat ditakuti. Padahal sebenarnya Ular Renggiong tidak akan memakan manusia. Sebaliknya, ia sebenarnya adalah seorang penjaga (guardian) yang tidak akan mengganggu manusia. Ia juga berjanji memberikan api kepada tiga bersaudara perempuan tersebut asalkan permintaannya dikabulkan.

\section{Sekuen II}

Ibu merasa kesal. Kalau begini caranya mereka bisa mati kelaparan. Si Sulung dan Tengah kembali ke rumah dengan tangan kosong. Si Bungsu kemudian menawarkan dirinya untuk meminta api kepada Ular Renggiong. Ibunya merasa kasihan. Bagaimana jika nasib Si Bungsu sama saja dengan kedua kakaknya? Si Bungsu sudah membulatkan tekadnya. Ia akan pergi meminta api kepada Ular Renggiong apapun yang terjadi. Kedua kakaknya pun dengan senang hati menyuruh $\mathrm{Si}$ Bungsu pergi. Mereka lebih senang mengorbankan adiknya daripada mati kelaparan di rumah.

$\mathrm{Si}$ Bungsu akhirnya menemui Ular Renggiong dan menyampaikan maksudnya untuk meminta api. Ular Renggiong ternyata masih menawarkan hal yang sama. Ia berniat menjadikan $\mathrm{Si}$ Bungsu sebagai istrinya. $\mathrm{Si}$ Bungsu mengangguk mengiyakan permintaan Ular Renggiong. Mereka pun berangkat bersama menuju rumah Si Bungsu untuk menyalakan api.

Ular Renggiong dan Si Bungsu sampai di rumah sementara kakak dan ibunya telah menunggu di sana. Setelah menyalakan api dan memasak, mereka makan bersamasama. Ular Renggiong menyampaikan kembali niatnya untuk menikahi Si Bungsu. Mendengar hal tersebut, Si Sulung dan Tengah berulang kali mengolok Si Bungsu. Mereka mendesak supaya Si Bungsu tidak usah menepati janjinya kepada Ular Renggiong. Toh mereka sudah mendapat api yang diinginkan. Meskipun demikian, $\mathrm{Si}$ Bungsu tetap menepati janjinya. Mereka tetap menikah sesuai dengan permintaan Ular Renggiong.

Ular Renggiong akan memberikan api seperti yang diminta oleh tiga bersaudara perempuan tetapi dengan mengajukan syarat pernikahan. Si Sulung dan Tengah jelas menolak permintaan Ular Renggiong dengan alasan mana mungkin menikah dengan hewan mengerikan seperti itu. Si Bungsu akhirnya menerima syarat tersebut agar ibu dan kedua saudara perempuannya yang lain tidak kelaparan. Hal ini sesuai dengan motif C26 Wish for animal husband realized (girls says she will marry a certain animal).

Dengan penuh keberanian, si Bungsu menerima syarat yang diajukan Ular 
Dwi Oktarina: Keberagaman Motif dalam Cerita Rakyat Ular Renggiong dan...

Renggiong. Ia bersedia diperistri dan menikah meski Ular Renggiong adalah ular yang berbentuk menyeramkan. Peristiwa ini sesuai dengan motif cerita B604.1 Marriage to a snake dan B646 Marriage to person in snake form.

Dalam berbagai mitos dan legenda dunia, banyak cerita yang mengisahkan perkawinan antara ular dengan manusia. Ashlima (2014) menyebut beberapa cerita yang berisi perkawinan ular dengan manusia. Misalnya, "The River Snake" dari India yang mengisahkan perkawinan ular sungai dengan seorang perempuan dari desa. Ada pula dongeng dari Italia yang berjudul "The Serpent" yang mengisahkan seorang ular yang berkeinginan menikah dengan putri kerajaan. Ia harus mengubah dinding istana menjadi menjadi emas jika ingin menikah dengan sang putri. Kisah lain dari Jerman, yakni "Oda and the Snake", mengisahkan pernikahan antara tokoh utama perempuan bernama Oda dengan seekor ular yang dibawa pulang oleh ayahnya dan kemudian berubah menjadi pangeran tampan.

Menikah dengan sosok yang bukan manusia apalagi binatang adalah hal yang wajar dalam cerita-cerita mitos. Hal ini pun terjadi dalam cerita "Ular Renggiong". Meskipun pada awalnya dilanda ketakutan, si Bungsu memiliki kedewasaan dalam berpikir dan bertindak. Hal ini juga yang membuat ia mengiyakan permintaan Ular Renggiong yang meminta dirinya untuk menikah.

\section{Sekuen III}

Pernikahan pun terjadi. Ajaibnya, pada hari yang sakral itu, Ular Renggiong berubah menjadi laki-laki yang sangat tampan. Akhirnya ia menceritakan jati dirinya yang sebenarnya. Dulu ia adalah anak seorang saudagar yang kaya. Ia kerap bertindak sewenang-wenang terhadap orang lain. akibatnya ia dikutuk menjadi Ular Renggiong dan kutukan itu hanya akan hilang jika ia bertemu dengan perempuan yang benar-benar mencintainya. Ternyata $\mathrm{Si}$ Bungsu yang menjadi penyelamat hidupnya.

Melihat hal tersebut, sang Ibu bersyukur. Tidak demikian dengan kedua kakaknya yang merasa iri. Mereka sepakat mencari ular lain di hutan dan berharap jika menikah dengan ular tersebut nasibnya akan bagus seperti adiknya yang baik hati. Sayangnya hal tersebut tidak terjadi. Kedua kakak Si
Bungsu mati dipatuk ular di dalam hutan karena kecerobohan dan sifat iri dengki yang mereka miliki.

Dalam sekuen III ini, ditemukan beberapa motif yang relevan. Motif pertama, yakni B650.1 Animal transformed to man wants to marry woman dan D391 Transformation: serpent (snake) to person. Motif transformasi dari ular menjadi manusia atau sebaliknya juga banyak terdapat di cerita-cerita klasik.

Ular Renggiong pada awalnya adalah seorang manusia dikutuk karena sikapnya yang tidak baik dan sewenang-wenang terhadap orang lain. Motif transformasi ini adalah sebagai upaya terkait pembelajaran agar seseorang berubah menjadi lebih baik dari sebelumnya. Sifat yang harus disingkirkan adalah iri dengki, ketamakan, sikap sewenang-wenang, kemalasan, dan kebodohan.

Dalam proses transformasi yang terjadi, hal itu tidak hanya bersifat metafisik/transendental, tetapi juga bersifat simbolis. Seseorang atau binatang yang mengalami transformasi akan berubah menjadi wujud lain yang berbeda dengan sebelumnya. Selain itu, cara berpikir bahkan status sosialnya juga akan ikut berubah mengikuti perubahan yang dialami (Danisova, 2018: 1).

Creany (2013: 30) menyebut bahwa bagian transformasi pada kisah-kisah legenda adalah bagian paling kuat dan berpengaruh dalam penceritaan. Dua kisah paling terkenal yakni Beauty and the Beast dan Frog Princess. Kedua kisah tersebut sama-sama bercerita tentang transformasi binatang menjadi sosok manusia yang menawan.

Dalam banyak kisah, banyak transformasi yang terjadi dalam rangka upaya hukuman sekaligus pembelajaran. Satu legenda asal Bulgaria berjudul "The Three Sisters" bercerita mengenai anak perempuan yang dikutuk menjadi kura-kura karena malas merawat ibunya yang sedang sakit keras. Selain itu, ada kisah Raja Midas yang menghina Dewa Apollo. Apollo kemudian menghukum dengan cara mengubah kuping Raja Midas menjadi kuping keledai sebagai simbol kebodohan dan sifat keras kepala (Becker dalam Danisova, 2018: 26). 
Dwi Oktarina: Keberagaman Motif dalam Cerita Rakyat Ular Renggiong dan...

Meskipun sudah memilih menikah dengan Ular Renggiong, keputusan si Bungsu tetap diremehkan oleh kedua saudarinya. Akan tetapi, saat melihat Ular Renggiong berubah menjadi sosok lelaki tampan, mereka pun berubah sikap menjadi cemburu juga iri dan dengki. Hal ini sesuai dengan motif cerita L54.1 Youngest daughter agrees to marry a monster; later the sister are jealous.

Karena berharap akan mendapatkan laki-laki setampan Ular Renggiong, kedua saudari Si Bungsu akhirnya memilih masuk ke hutan dan mencari ular agar bisa menikah dengannya. Pencarian mereka sia-sia karena sifat iri dan dengki yang dimiliki. Mereka tidak mendapat apa yang diinginkan melainkan mati dipatuk ular di dalam hutan.

Kesia-siaan adalah hal yang akan didapatkan jika seseorang bersifat iri dan dengki kepada orang lain. Hal ini tergambar dalam kehidupan tiga bersaudara ini. Sulung dan Tengah yang tidak bisa bersikap tulus merasa iri dengan keberuntungan yang didapatkan Bungsu. Oleh sebab itu, mereka mendapatkan ganjaran yang setimpal di akhir hidupnya.

\subsection{Cerita "Putri Gunung Labu" Sekuen I}

Sekian lama berumah tangga, Kulup Manau dan Mak Dambe belum juga dikaruniai keturunan. Mereka banyak mendapat sindiran dari orang-orang. Mak Dambe bahkan dianggap sebagai perempuan terasing yang dapat menularkan penyakit. Pekerjaan utama Kulup Manau adalah memarang rotan. Ia kerap pergi cukup jauh dari kampung. Untuk mengisi waktu, Mak Dambe sering mandi di telaga utan riding meskipun ia tahu bahwa hutan tersebut adalah hutan terlarang untuk dimasuki. Mak Dambe terbiasa masuk keluar hutan tersebut hingga hewan-hewan sudah biasa melihatnya. Ia sering bersenandung lagu penuh ratapan atas nasib yang ia alami.

Suatu ketika saat pulang memarang rotan, Kulup Manau dan Mak Dambe berjalan melintasi utan riding dan mendengarkan suara tangis bayi. Mereka terkejut sembari mencari sumber suara. Mereka pun menemukan seorang bayi perempuan yang diselimuti kain tenun halus. Siapa yang tidak terkejut menemukan seorang bayi di tengah hutan. Mereka pun setuju untuk membawa si bayi pulang. Bayi tersebut dipanggil dengan nama Putri karena mereka tidak tahu namanya.

Tokoh utama dalam cerita ini adalah pasangan suami istri yang bernama Kulup Manau dan Mak Dambe. Dalam bahasa Melayu Belitung, "dambe" bermakna "damba". Mereka memang pasangan suami istri yang telah lama menginginkan kehadiran seorang anak. Akan tetapi, Tuhan belum mengizinkan hal tersebut terjadi. Rasa cinta mereka berdua diuji dengan belum hadirnya anak di tengahtengah mereka hingga bertahun-tahun lamanya. Motif yang sesuai dengan kondisi tersebut adalah H491. Test of mother's and father's love for children.

Meskipun diuji dalam waktu yang lama, pasangan ini sama sekali tidak menjadi goyah. Mereka tetap menjalankan kegiatan sehari-hari sekaligus berserah kepada Tuhan. Orang-orang di sekitar mereka banyak mengejek dan menertawakan, tetapi hal itu tidak dijadikan sumber masalah oleh mereka. Desakan tetangga dan masyarakat membuat pasangan suami istri itu berupaya sekuat tenaga dalam mendapatkan keturunan. Hal ini sesuai dengan motif H494. Maternity test: to produce a baby within a year. Usia yang sudah tidak muda lagi juga menjadi alasan. Mak Dambe bahkan dijauhi perempuan lain karena dianggap akan menulari "penyakitnya" itu.

Dalam kisah ini, ada satu motif yang tampak menonjol, yakni motif D940. Magic forest atau hutan sihir/gaib. Hutan yang menjadi latar tempat menemukan seorang bayi disebut utan riding. Utan riding yang ada di cerita adalah sebuah hutan terlarang yang tidak boleh dimasuki sembarang orang.

Makna simbolik dari keberadaan pohon dan hutan telah lama ada dalam kehidupan manusia. Pepohonan dan hutan sangat memengaruhi kehidupan masyarakat. Sama halnya dengan gunung atau batubatuan besar yang dianggap sakral, pepohonan dan hutan dianggap pula sebagai sesuatu yang ajaib dan dapat membawa manusia ke alam yang lain (Crews, 2003).

Dalam berbagai sistem budaya, hutan juga memiliki posisi fungsi yang berbedabeda. Di Rusia, hutan dianggap sebagai 
Dwi Oktarina: Keberagaman Motif dalam Cerita Rakyat Ular Renggiong dan...

tempat sakral yang biasanya dipenuhi dengan energi negatif yang sangat besar (Limerov, 2020: 129). Oleh sebab itu, hutan harus dihindari. Hal ini selaras dengan larangan memasuki utan riding. Orang-orang seharusnya menghargai dan percaya akan kekuatan yang lebih besar yang tidak dimiliki oleh manusia. Selain itu, motif lain larangan memasuki utan riding adalah untuk menjaga keberlangsungan ekosistem hayati yang ada di dalamnya. Jika manusia dilarang masuk ke hutan, kondisi lingkungan dan sumber daya yang ada di dalamnnya akan tetap terjaga.

Salah satu bagian penting yang akan menjadi penanda dalam cerita ini adalah keberadaan kain penutup bayi saat Mak Dambe dan Kulup Manau menemukan Putri untuk pertama kalinya. Hal ini sesuai dengan motif D1061. Magic veil.

Kain atau selendang penutup bayi itu adalah kain tenuh berwarna merah. Pada saat ditemukan, kain itu tidak mengundang kecurigaan karena hanya digunakan untuk menutupi tubuh bayi mungil. Namun, pada akhir cerita, baru diketahui bahwa sebenarnya kain tenun tersebut adalah kain ajaib yang akan menuntun Putri kembali ke asalnya. Itulah alasan kain tersebut sebenarnya memiliki kekuatan sihir atau gaib.

\section{Sekuen II}

Orang-orang di kampung merasa heran karena tiba-tiba saja Kulup Manau dan Mak Dambe pulang ke rumah dengan membawa bayi yang tidak jelas asal-usulnya. Lamakelamaan berita jelek pun tersebar. Anak yang tidak jelas asal-usulnya tersebut bisa membawa bala musibah kepada seluruh penduduk kampung. Oleh sebab itu, penduduk harus mengusir si bayi. Mak Dambe dan Kulup Manau tidak tinggal diam. Mereka akhirnya berpamitan kepada warga kampung untuk mengantar bayi tersebut ke sebuah padang di luar kampung mereka. Tiba-tiba saja keesokan harinya Mak Dambe dan Kulup Manau juga tidak bisa ditemukan. Mereka menghilang. Sejak saat itu, padang tersebut disebut sebagai Padang Buang Anak.

Dalam fragmen Sekuen II, Kulup Manau dan Mak Dambe akhirnya membawa pulang bayi yang mereka temukan di utan riding. Hal ini sesuai dengan motif R131. Exposed or abandoned child rescued.
Suardi (2012) menjelaskan bahwa motif pengabaian anak, yang hampir semua terjadi saat anak baru dilahirkan, merupakan satu tema yang sudah ada bahkan di mitos-mitos, legenda, bahkan literatur keagamaan. Musa ditemukan oleh Firaun dan kemudian tumbuh besar menjadi pemimpin Bani Izrail. Ia ditemukan dalam sebuah keranjang di aliran Sungai Nil. Cerita lain, yakni tentang Romulus dan Remus yang diabaikan oleh orang tuanya dan dibesarkan oleh serigala hingga akhirnya mereka mendirikan kota Roma dan menjadi raja di sana.

Mak Dambe maupun Kulup Manau sama sekali tidak mengetahui asal usul bayi yang mereka temukan. Akan tetapi, mereka membawa pulang bayi tersebut dan berkeinginan untuk merawatnya seperti anak sendiri. Namun, desas-desus yang berkembang di kampung sama sekali tidak beralasan. Orang-orang kampung menganggap bahwa anak yang tidak diketahui asal-usulnya dapat membawa musibah untuk orang-orang di kampung.

Karakter bayi yang ditemukan Kulup Manau dan Mak Dambe adalah yatim piatu. Dalam literatur dan cerita rakyat, sosok anak yatim piatu menyimbolkan keterasingan antara dirinya dengan masyarakat. Anak yang tidak diketahui asal-usulnya dianggap membawa ketidakberuntungan. Selain itu, kadang hidup anak yatim piatu sangat menderita karena perlakukan yang diterimanya. Anak yatim piatu tidak memiliki keluarga sebagai penopang utama. Meminjam istilah Homi K. Bhabha, kadang anak yatim piatu dianggap sebagai Liyan (The Other) yang harus disingkirkan dari kehidupan bermasyarakat (Kimbal, 1999: 559).

$\mathrm{Hal}$ ini juga dialami oleh sang bayi yang ditemukan di utan riding. Karena tidak mau penduduk kampung mengusir bayi mungil yang baru mereka bawa pulang, akhirnya Kulup Manau dan Mak Dambe berniat membawa bayi tersebut ke sebuah padang di luar kampung. Namun, yang terjadi adalah mereka semua menghilang secara misterius. Masyarakat sama sekali tidak menyangka bahwa pasangan suami istri beserta bayi tersebut akan menghilang begitu saja. Seisi kampung pun menjadi dicekam rasa ketakutan seusai peristiwa itu terjadi. 
Dwi Oktarina: Keberagaman Motif dalam Cerita Rakyat Ular Renggiong dan...

\section{Sekuen III}

Kulup Manau dan Mak Dambe membesarkan Putri di sebuah kubok. Putri tumbuh menjadi seorang gadis rupawan saat dewasa. Tak terasa, sudah datang waktunya usia untuk menikah bagi Putri. Banyak orang ingin melamarnya. Berita kecantikannya pun akhirnya terdengar jauh hingga ke telinga Pangeran Ki Galong. Ia bertekad menikah dengan sang Putri meski harus menyamar terlebih dulu untuk menguji kebaikan hati sang Putri. Singkat cerita, keduanya pun akhirnya menikah dan hidup bersama.

Pada dasarnya, Mak Dambe, Kulup Manau, dan bayi yang masih merah tersebut tidak menghilang. Pasangan suami istri tersebut berusaha sekuat tenaga untuk bersembunyi hingga tak ada orang yang mengetahui keberadaan mereka. Hal ini sesuai dengan motif cerita, yakni D1870. Magic hideousness dan D1872. Man made hideous. Proses mereka menghilang tidak mungkin terjadi tanpa adanya bantuan keajaiban dan kekuatan yang ada di luar batas nalar manusia.

Mereka dapat memulai hidup dengan baik di sebuah kubok (permukiman yang jauh dari orang ramai). Bayi tersebut tumbuh menjadi perempuan yang sangat cantik. Ia pun diberi nama Putri. Berita tentang kecantikannya terdengar jauh hingga melintasi batas wilayah yang ada. Seorang pangeran pun ingin berjumpa dengannya dan merasa ingin menjadikan Putri sebagai pendamping hidupnya. Akan tetapi sebelum itu, ia harus mengetes sifat Putri. Apakah Putri layak untuk dijadikan permaisuri bagi Pangeran Ki Galong. Hal ini sesuai dengan motif H338. Suitor test: faithfulness.

Tes yang dilakukan Pangeran Ki Galong untuk menguji apakah Putri adalah sosok yang tepat untuk menjadi permaisuri adalah dengan menyamar menjadi pengemis yang meminta belas kasihan Putri. Dengan kerendahan hati yang dimilikinya, Putri tentu saja bersedia menolong. Ia tidak membeda-bedakan dalam hal menolong sesama manusia. Dengan demikian, ia pun lulus ujian untuk menjadi calon permaisuri Pangeran Ki Galong. Kejujuran dan kerendahan hati menerima orang lain tanpa membeda- bedakan membuat pangeran jatuh hati kepada Putri. Keputusan keduanya untuk menikah pun sesuai dengan motif cerita M331. Princess to marry prince.

\section{Sekuen IV}

Sekian waktu berlalu, Pangeran Ki Galong naik tahta. Sebagai permaisuri, Putri mendampingi dengan baik. Meski demikian, orang iri dan dengki tentu saja masih terus saja berupaya menghancurkan kebahagiaan mereka. Asal usul Putri dipertanyakan orang-orang. Menurut Datuk Pasai yang menjadi orang kepercayaan istana, Putri adalah orang Bunian (makhluk halus). Sang Raja merasa bingung dan sedih hatinya. Melihat hal tersebut, Putri berkata bahwa Raja harus bertarung dengan Datuk Pasai jika memang itu perlu dilakukan untuk membuktikan desas-desus tersebut. Putri menyerahkan sebuah jarum yang bisa digunakan sebagai senjata untuk membunuh Datuk Pasai. Ternyata apa yang dikatakan istrinya betul. Pertarungan tak bisa dielakkan dan Datuk Pasai menemui ajalnya akibat jarum kecil tersebut.

Dalam fragmen ini, terdapat motif yang sesuai yaitu P13.5 Crownings of kings. Pangeran Ki Galong akhirnya menjadi pemimpin tertinggi di kerajaannya. Penobatan sebagai raja tentu setelah melewati berbagai ujian. Sementara itu, Putri menjadi permaisuri yang setia mendampingi.

Cobaan datang kepada pasangan suami istri ini saat desas-desus mengenai Putri terkuak. Banyak orang menyangsikan asalusul sang permaisuri. Bahkan Datuk Pasai menyebut Putri sebagai urang bunian (keturunan makhluk halus). Demi membuktikan isu yang sudah beredar, sang raja harus berhadapan dengan Datuk Pasai. Dalam menghadapi pertempuran, Permaisuri memberikan senjata berupa jarum ajaib. Hal ini sesuai dengan motif D1181 Magic needle.

Senjata rahasia berupa jarum tersebut akhirnya dapat membunuh Datuk Pasai. Hal ini juga sesuai dengan motif D1402.7 Magic weapon kills. Dalam sejarahnya, senjata ajaib kerap diasosiasikan dengan cerita-cerita mitos dan fantasi. Salah satu senjata ajaib yang dikenal adalah palu ajaib milik Thor, Mjölnir. Selain palu ajaib, senjata lain yang juga sering hadir dalam keberadaan cerita-cerita klasik adalah 
Dwi Oktarina: Keberagaman Motif dalam Cerita Rakyat Ular Renggiong dan...

pedang, pisau, baju zirah, dan panah. Senjata ajaib dapat mengandung kekuatan khusus yang ada di luar nalar manusia. Kekuatan yang dimilikinya melampaui waktu, budaya, bahkan kepercayaan (Dahm, 2020). Dalam cerita Putri Gunung Labu ini, alat yang memiliki kekuatan khusus ini adalah sebuah jarum yang dimiliki sang permaisuri sejak ia masih bayi saat ditinggalkan di tepi hutan bersama dengan selendang tenun berwarna merah.

\section{Sekuen V}

Waktu berlalu. Sang Raja pada akhirnya mangkat. Hal ini membuat istrinya makin bersedih. Ia seperti tak hendak hidup di dunia lagi. Istana yang ditinggalinya terasa hampa. Putri teringat akan asal-usulnya. Mak Dambe dulu mengatakan kepadanya bahwa ia harus bertemu dengan orang tua kandungnya sebelum pergi meninggalkan dunia. Mak Dambe mengatakan bahwa orang tuanya hanya meninggalkan sebuah kain tenun berwarna merah untuk menyelimuti Putri saat masih bayi.

Suatu hari, penduduk kampung melihat satu cahaya melesat di atas istana Putri. Ternyata itu adalah selembar kain tenun merah yang terbang di atas istana yang berada di Gunung Labu tersebut. Sejak saat itu ternyata sang Putri menghilang dan tidak diketahui keberadaannya. Istana yang awalnya terawat menjadi terbengkalai dan hanya ada siswa-sisa reruntuhan. Tidak ada lagi penduduk yang berani mendekati Gunung Labu sehingga wilayah itu kemudian menjadi kosong dan dijauhi semua orang.

Kepergian sang raja membuat permaisuri bersedih hati. Ia tak menyangka jika akan ditinggal mati oleh suaminya. Ia mengurung diri dalam istananya. Hal ini sesuai dengan motif T85. Woman mourns dead lover. Rasa frustrasi dan sedih membuat ia memikirkan asal-usulnya. Beban yang ditanggung seakan-akan tak bisa ia terima. Ia memilih untuk kembali pada jati diri dan asal-usulnya.

Tanpa disangka, selembar kain tenun merah yang dulu ditinggalkan bersama dirinya saat masih bayi adalah yang membawanya pergi menuju dunia yang seharusnya ia tuju. Hal ini sesuai dengan motif D2120. Magic transportation. Orangorang tak menyangka bahwa permaisuri akan menghilang dari istananya. Hal ini juga sesuai dengan motif D1418 Magic object causes person to become lost. Sejak saat itu pula, istana terbengkalai tanpa ada satu pun orang tinggal di dalamnya. Masyarakat pun tak ada yang berani mendekat ke istana tersebut untuk mencari tahu keberadaan sang permaisuri yang telah menghilang menuju dunianya.

\section{SIMPULAN}

Cerita "Ular Rengiong" memiliki sembilan motif sementara "Putri Gunung Labu" memiliki 15 motif bila dikaji berdasarkan teori Motif Indeks Thompson. Hal ini menandakan keberagaman motif cerita yang ada di wilayah Belitung Timur.

Dari kedua cerita yang telah dikaji berdasarkan motif indeks Thompson, daftar motif secara terperinci dapat dilihat pada tabel berikut.

\section{Tabel 1 \\ Daftar Motif}

\begin{tabular}{|c|c|c|}
\hline No. & $\begin{array}{c}\text { "Ular } \\
\text { Renggiong" }\end{array}$ & $\begin{array}{c}\text { "Putri Gunung } \\
\text { Labu" }\end{array}$ \\
\hline 1 & $\begin{array}{l}\text { P252.2 Three } \\
\text { Sisters }\end{array}$ & $\begin{array}{l}\text { H491. Test of } \\
\text { mother's and } \\
\text { father's love for } \\
\text { children }\end{array}$ \\
\hline 2 & $\begin{array}{l}\text { P236. Undutiful } \\
\text { Children }\end{array}$ & $\begin{array}{l}\text { H494. Maternity } \\
\text { test: to produce } \\
\text { a baby within a } \\
\text { year }\end{array}$ \\
\hline 3 & $\begin{array}{l}\text { B211.61 } \\
\text { Speaking Snake }\end{array}$ & $\begin{array}{l}\text { D940. Magic } \\
\text { forest }\end{array}$ \\
\hline 4 & $\begin{array}{l}\text { C26 Wish for } \\
\text { animal husband } \\
\text { realized (girls } \\
\text { says she will } \\
\text { marry a certain } \\
\text { animal) }\end{array}$ & $\begin{array}{l}\text { D1061. Magic } \\
\text { veil }\end{array}$ \\
\hline 5 & $\begin{array}{l}\text { B604.1 } \\
\text { Marriage to a } \\
\text { snake }\end{array}$ & $\begin{array}{l}\text { R131. Exposed } \\
\text { or abandoned } \\
\text { child rescued }\end{array}$ \\
\hline 6 & $\begin{array}{l}\text { B646 Marriage } \\
\text { to person in } \\
\text { snake form }\end{array}$ & $\begin{array}{l}\text { D1870. Magic } \\
\text { hideousness }\end{array}$ \\
\hline 7 & $\begin{array}{l}\text { B650.1 Animal } \\
\text { transformed to } \\
\text { man wants to } \\
\text { marry woman }\end{array}$ & $\begin{array}{l}\text { D1872. Man } \\
\text { made hideous }\end{array}$ \\
\hline 8 & $\begin{array}{l}\text { D391 } \\
\text { Transformation: } \\
\text { serpent (snake) } \\
\text { to person }\end{array}$ & $\begin{array}{l}\text { H338. Suitor } \\
\text { test: faithfulness. }\end{array}$ \\
\hline
\end{tabular}


Dwi Oktarina: Keberagaman Motif dalam Cerita Rakyat Ular Renggiong dan...

\begin{tabular}{|c|c|c|}
\hline 9 & $\begin{array}{l}\text { L54.1 Youngest } \\
\text { daughter } \\
\text { agrees to marry } \\
\text { a monster; } \\
\text { later the sister } \\
\text { are jealous }\end{array}$ & $\begin{array}{l}\text { M331. Princess } \\
\text { to marry prince }\end{array}$ \\
\hline 10 & & $\begin{array}{l}\text { P13.5 Crownings } \\
\text { of kings }\end{array}$ \\
\hline 11 & & $\begin{array}{l}\text { D1181 Magic } \\
\text { needle }\end{array}$ \\
\hline 12 & & $\begin{array}{l}\text { D1402.7 Magic } \\
\text { weapon kills }\end{array}$ \\
\hline 13 & & $\begin{array}{l}\text { T85. Woman } \\
\text { mourns dead } \\
\text { lover }\end{array}$ \\
\hline 14 & & $\begin{array}{l}\text { D2120. Magic } \\
\text { transportation. }\end{array}$ \\
\hline 15 & & $\begin{array}{l}\text { D1418 Magic } \\
\text { object causes } \\
\text { person to } \\
\text { become lost }\end{array}$ \\
\hline
\end{tabular}

Dalam cerita "Ular Renggiong", sosok ular yang garang dan kasar bertransformasi menjadi pangeran yang tampan. Sementara itu, dalam cerita "Putri Gunung Labu", sang Putri sebenarnya adalah sosok yang memiliki kekuatan supranatural dibanding orang-orang pada umumnya.

\section{DAFTAR PUSTAKA}

Aliana, Zainal Arifin, dkk. (1992). Sastra Lisan Bahasa Melayu Belitung. Jakarta: Pusat Pembinaan dan Pengembangan Bahasa, Departemen Pendidikan dan Kebudayaan.

Ashlima, D.L. (2014). "Snake and Serpent Husbands; Folktales of Type 433C and related stories," dalam https://www.pitt.edu/ dash/snake.h tml\#girlandsnake, diakses 30 April 2020 pukul 11.09 WIB.

Chatman, Seymour. (1975). "Towards a Theory of Narrative," New Literary History, Vol. 6, No. 2, On Narrative and Narratives, hlm. 295-318. Diakses 29 Mei 2020 pukul 05.12 WIB

https://www.jstor.org/stable/468421 ?read- now $=1 \&$ seq $=23 \#$ page scan tab co ntents

Creany, Anne Drolet. (2013). "Who is the beast? The portrayal of animals in multicultural folklore," Journal of the European Teacher Education Network, Vol. 8. HIm. 25-34.

Crews, Judith. (2003). "Forest and tree symbolism in folklore," dalam https://www.researchgate.net/public ation/293528023 Forest and tree s ymbolism in folklore published in UNASYLVA an international journal of forestry and forest industries $p$ ublished by the Forestry Division 0 $f$ the Food and Agriculture Organiz ation of th diakses 2 Mei 2020 pukul 10.00 WIB.

Dahm, Murray. (2020). "No weapon could bite him- Magic weapons and armour in the middle ages," dalam https://www.academia.edu/3101688 6/No weapon could bite him Magic weapons and armour in the midd le ages diakses 2 Mei 2020 pukul 06.27 .

Danandjaja, James. (1984). Folklor Indonesia: IImu Gosip, Dongeng, dan lain-lain. Jakarta: Pustaka Utama Grafiti.

Danisova, Nikola. (2018). "Animal transformation as a deserve punishment in archnarratives," Jurnal Ars Aeterna, Vol. 10, No. 2, hlm. 18-31, dalam https://www.researchgate.net/public ation/331122559 Animal transforma tion as a deserved punishment in archnarratives diakses 1 Mei 2020 pukul 05.16 WIB.

Herawati, Yudianti. (2019). "Cerita Rakyat 'Aji Batara Agung Dewa Sakti' dan 'Putri Karang Melenu' dari Kutai Kartanegara (Kajian Motif Indeks Thompson). Jurnal Jentera Vol. 7, No. 1 , hlm 48-66.

Ibrahim dkk. (2015). "Kajian Sastra Lisan Bangka Belitung," laporan penelitian tidak diterbitkan. Pangkalpinang: Dinas Kebudayaan dan Provinsi Kepulauan Bangka Belitung. 
Dwi Oktarina: Keberagaman Motif dalam Cerita Rakyat Ular Renggiong dan...

Imelda. (2015). "Perbandingan Cerita Rakyat Si Kelingking (Jambi dan Bangka Belitung)", Jurnal Madah Vol. 6, No. 1, hlm. 101-112.

Isral, Larsi de (Ed). (2018). Cerita Rakyat dari Belitung Timur. Manggar: Dinas Kebudayaan dan Pariwisata Kabupaten Belitung Timur.

Kimball, Melanie A. (1999). "From Folktales to Fiction: Orphan Characters in Children's Literature," Library Trends, Vol. 47, No. 3, hlm 558-578.

Limerov, Pavel F. (2020), "Forest Myths: A Brief Overview of Ideologies Before St. Stefan," dalam https://www.folklore.ee/folklore/vol3 0/limerov.pdf diakses pada $2 \mathrm{Mei}$ 2020, pukul 05.51 WIB.

Nunez, Eloy Martos, dkk. (2015). "The Serpent as a Pan-Mediterranean Myth", Mediterranean Journal of Social Sciences, Vol. 6, No. 4, hlm. 422-431.

Riana, Derri Ris. (2017). "Pemaknaan Motif Tabu dalam Cerita Rakyat di Wilayah Bekas Kerajaan Mulawarman, Kerajaan Hindu Tertua di Indonesia," Jurnal Aksara, Vol. 29, No. 2, hlm. 197-209.

Sarman. (2014). "Mitos dalam Cerita Bukit Tambun Tulang," Jurnal Sirok Bastra, Vol. 2, No. 1, hlm. 17-24. . (2016). "Representasi Kearifan Lokal Masyarakat Belitung dalam Cerita Keramat Pinang Gading," Jurnal Sirok Bastra, Vol. 4, No. 2, hlm. 153-160.
. (2017). "Analisis Struktur Aktan dan Fungsional Dongeng Batu Karang Seribu," Jurnal Sirok Bastra, Vol. 5, No. 1, hlm. 65-71. . (2019). "Cerita Batu Bagga dan Batu Balai: Sebuah Kajian Struktural Sastra Bandingan," Jurnal Sirok Bastra, Vol. 7, No. 1, hlm. 1-8.

Suardi, Enrico. (2012). "The Kindness of Strangers in the face of Child Abandonment," dalam https://www.psychiatrictimes.com/ch ild-adolescent-psychiatry/kindnessstrangers-face-child-abandonment, diakses 4 Mei 2020 pukul 11.19 WIB.

Taum, Yoseph Yapi. (2011). Studi Sastra Lisan: Sejarah, Teori, Metode, dan Pendekatan Disertai Contoh Penerapannya. Yogyakarta: Penerbit Lamalera.

Thompson, Stith. (1946). The Folktale. New York: The Dryden Press. . (1958). Motif Index of Folk Literature; A Classification of Narrative Elements in Folktales, Ballads, Myths, Fables, Medieaval Romances, Exempla, Fabliaux, J estBooks, and Local Legends revised edition. Copenhagen: Rosenkilde and Bagger.

Wake, Staniland. (2020). "The Origin or Serpent-Worship" dalam https:/www.jstor.org/stable/2841458 , diakses pada 30 April 2020 pukul 03.28 WIB. 